\title{
The influence of compensation, training and development on organisational citizenship behaviour
}

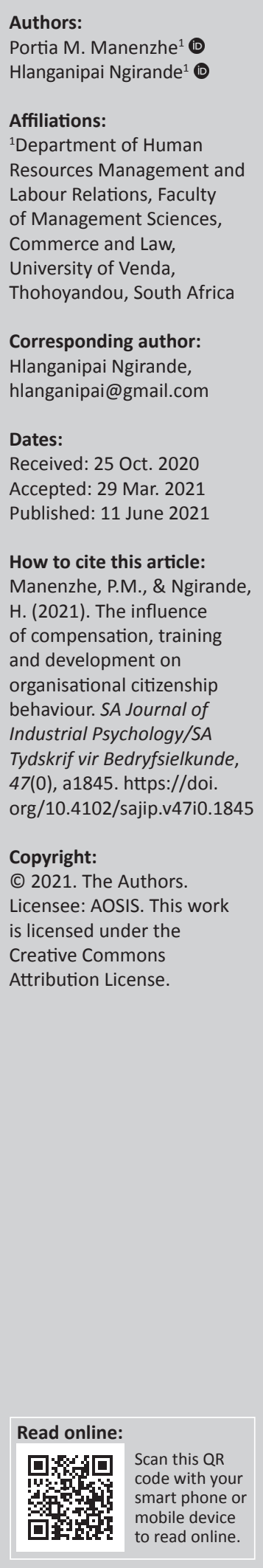

Orientation: Extra role behaviours, also known as organisational citizenship behaviours, are very important for an organisation's success. Organisational objectives can be efficiently achieved when employees are willing to do work that is beyond their job description. Organisations with employees with high organisational citizenship behaviour have a competitive advantage and are highly productive

Research purpose: The study investigated the influence of compensation and training and development on organisational citizenship behaviour amongst academic staff at a rural-based South African institution of higher learning.

Motivation for the study: Research on the influence of compensation and training and development on organisational citizenship behaviour is not new. However, the studies were carried out in different sectors outside South Africa. There is still scant information known about citizenship behaviour in the higher education sector in general and in South African rural-based institutions of higher learning in particular.

Research approach/design and method: The study was based on a quantitative approach, which used a cross-sectional research design. A sample of 152 academic staff participated in this study. Data were gathered using a self-administered questionnaire. Descriptive statistics, correlation and multiple regression analysis technique were conducted using Statistical Package for Social Sciences (SPSS) version 26.0.

Main findings: The findings revealed a significant relationship between compensation and organisational citizenship behaviour. A significant correlation was also found between training and development and organisational citizenship behaviour. However, in multiple regression analysis, compensation was found to be the only predictor of organisational citizenship behaviour. Moreover, no significant difference in levels of organisational citizenship behaviour between men and women was found.

Practical/managerial implications: The management of the institution should continuously review its compensation or rewards policies to enhance organisational citizenship behaviour amongst the academic staff. Institutions of higher learning should also compensate their employees and develop them fairly regardless of gender in order to promote organisational citizenship behaviour.

Contribution/value-add: The study's findings will assist the university management in making strategic decisions on compensation systems and staff development that will enhance the citizenship behaviour of the academic staff.

Keywords: academic staff; compensation; higher education; human resource management practices; organisational citizenship behaviour; South Africa; training and development; university.

\section{Introduction}

Extra role behaviours, also known as organisational citizenship behaviours, are very important for an organisation's success. Organisational objectives can be efficiently achieved when employees are willing to do work that is beyond their job description (Chattopadhyay, 2017). Organisations with employees with high organisational citizenship behaviour have a competitive advantage and are highly productive (Morales-Sánchez \& Pasamar, 2019; Rawabdeh, Nawafleh, Alsari, \& Melhem, 2019; Salas-Vallina, Alegre, \& Fernandez, 2017). However, few organisations have a clear organisational citizenship behaviour strategy. It is, therefore, crucial for organisations to align their human management practices to their strategic objectives (Tashtoush \& Eyupoglu, 2020). Tashtoush and Eyupoglu (2020) argued that the effective management of human resource 
management practices enhance the organisational citizenship behaviour of employees. Therefore, this study investigates the influence of compensation and training and development on organisational citizenship behaviour.

The South African higher education sector is currently facing different challenges and changes. These include massive increase in enrolment of students in excess of their capacity (Mohamedbhai, 2014). As most students have increased access to higher education, the literature has shown that access to quality learning and success rate (Boughey \& McKenna, 2016) is still a challenge because of large classes (Teferra, 2015), staff to student ratio imbalances, shortage of institutional resources and student diversity (Smit, 2012). Furthermore, the sector is faced with high employee mobility and gender disparities amongst the academic staff (Department of Higher Education and Training [DHET], 2015). These challenges mostly affect the under resourced institutions such as rural-based historically black universities (HBU) (Bozalek \& Boughey, 2012). In order to function effectively, higher education institutions are, to a large extent, dependent on the intellectual abilities and commitment of academic staff (Pienaar \& Bester, 2008; Theron, Barkhuizen, \& Du Plessis, 2014). It is, therefore, important to investigate the influence of compensation and training and development on organisational citizenship behaviour amongst the academic staff in the higher education sector.

\section{Compensation}

Compensation can be defined as the entire sum of monetary and non-monetary pay agreed to be given to an employee by the employer in return for work performed as required (Bussin \& Brigman, 2019). Compensation is further viewed as a mixture of the worth of one's remuneration, vacation, bonuses, health insurance and any other perks one may receive, including free lunches, complimentary events and parking (Odunlade, 2012). Compensation systems, therefore, are intended to reward past and influence future employee behaviours (Olson, Slater, Hult, \& Olson, 2018).

David (2013) identified two forms of compensation that are normally offered to employees, namely direct forms, which include wages, commissions, bonuses and hourly payments and indirect forms, which include equity-based programmes, retirements plans and paid vacations. These rewards should meet both the organisation's ability to pay and any governing legal regulations (Bussin, 2011). Employees who perceive their compensation to be adequate tend to put more effort than expected in their contracts of employment.

In addition to these forms of compensation, Chenga (2018) identified two categories of compensation, namely a jobbased approach and a skills-based approach. A job-based approach is where an individual is compensated for the job assigned regardless of the skills they possess (Milkovich, Newman, \& Gerhart, 2013) whereas, a skills-based approach is where an individual is paid for how skilled they are at performing the job or multiple tasks (Kim, Halliday, Zhao, Wang, \& Von Glinow, 2018). This study is premised on the skills-based approach because academics are compensated based on their skills.

Compensation is vital for employees as the amount of compensation imitates the size and value of their work (Boardman, Greenberg, Vining, \& Weimer, 2017) and influences their level of citizenship behaviour. As such, institutions of higher learning need to compensate human capital skills possessed by academic staff fairly and equitably for them to be competitive in terms of quality student learning and high throughput, which may be attributed to employees' extra effort. However, it is not compensation alone that inspires employees to put extra effort beyond their expectations. Employee development opportunities such as training and development may also influence one's level of organisational citizenship behaviour.

\section{Training and development}

Training and development refers to the process of giving employees instruction, seminars, coaching, mentoring and other learning opportunities that inspire, educate and enable them to serve their positions to the best of their knowledge within the requirements set by their organisation (Jahan, 2015). Organisations have many reasons for engaging in training and development. According to Organ, Podsakoff and MacKenzie (2006), training practices can encourage employees to upgrade their abilities and be more confident to complete their wider roles. Through better skills and confidence, employees may go beyond their expected normal duties.

The basic purpose of a training and development programme is to contribute to the overall goal achievement of an organisation. In addition, it improves knowledge, skills and transforms attitudes or behaviour of employees. Therefore, training and development can improve organisational citizenship behaviour within employees, leading to many benefits such as enhanced employees' confidence, satisfaction and comfortableness (Ahmed, 2016). The capacity of organisations to attain their objectives may be enhanced, thereby putting them in a more competitive position (Ford, Kraiger, \& Merritt, 2010; Zehra, 2016). This helps in employee retention, in the sense that employees value the opportunities that organisations offer them with regard to improving their learning (Elnagal \& Imran, 2013).

\section{Organisational citizenship behaviour}

Organisations are increasingly anticipating employees to go beyond their prescribed job descriptions and execute tasks that are out of their formal job descriptions and reward arrangements to cope with competitive forces (Dekas, Bauer, Welle, Kurkoski, \& Sullivan, 2013). According to Chin, Ho, Lim, Loh and Low (2017), organisational citizenship behaviour is exhibited when employees are willing to do work that is beyond their job description. Organisational citizenship behaviour can be viewed as a special part of work behaviour. It includes behaviour that is beneficial to the organisation which is not subject to formal rewards systems, but often part 
of the psychological contract between the individual and the organisation and hoped to be rewarded by the employer or organisation (Kolade, Oluseye, \& Omotayo, 2014).

According to Organ (1988), an employee who exhibits organisational citizenship behaviour helps others, complies with organisational norms, manages small matters internally and considers the effect an action might have on others, prior to taking it. An employee can show citizenship behaviour through civic virtue, which is the ability of being up to date with important matters in the organisation. Thus, organisational citizenship behaviour patterns may lead to organisational efficiency by providing effective ways to manage relationships between participants of the work unit, thereby improving the cumulative outcomes obtained (Ibrahim, Ghani, \& Salleh, 2013). Organisational citizenship behaviours also improve organisational efficiency and effectiveness by contributing to resource transformations, creativity and adaptability (Bonaparte, 2008). For the South African higher education sector to be efficient and effective, it requires academic staff that go beyond the call of their day to day duties when performing their work. The COVID-19 pandemic during 2019 and 2020 worsened challenges faced by the higher education sector in the country. For institutions of higher learning to remain productive in the knowledge production and for them to have a competitive advantage, their academic staff need to exhibit organisational citizenship behaviour. Hence, the sector needs to reward its human capital adequately and empower them with adequate skills through proper training. This may make academic staff more committed to their organisation and perform their duties beyond what is expected of them because of a positive psychological contract created with their organisation.

\section{The relationship between compensations and organisational citizenship behaviour}

Compensation can influence the organisational citizenship behaviour of employees because it is a payment for individual performance that can increase awareness and performance (Suryani, Gama, \& Prwita, 2019). Makau, Nzulwa and Wabala (2017) found that compensation has a significant positive relationship with organisational citizenship behaviour. Hence, it can inspire employees to contribute an extra effort in their jobs, thus contributing towards organisational citizenship behaviour. Findings from a research by Snape and Redman (2010) on employees in North-East England also revealed a positive effect of human resource management practices, compensation included, on organisational citizenship behaviour. One can, therefore, argue that a correlation exists between compensation and organisational citizenship behaviour.

A study conducted by Ahmed (2016) amongst banking staff in Sudan found that high compensation contributes to higher organisational citizenship behaviour. Similarly, a study conducted by Owor (2016) in selected firms in Uganda and another conducted by Tashtoush and Eyupoglu (2020) amongst administrators in Jordanian universities revealed that fair compensation is a significant predictor of organisational citizenship behaviour. Contrary to this, Patil and Ramanjaneyalu (2018) revealed that compensation has no significant impact on organisational citizenship behaviour. However, none of these studies focused on a historically disadvantaged rural-based university in South Africa.

\section{The relationship between training and development and organisational citizenship behaviour}

Through training and development, employees can become motivated to go an extra mile in doing their job (Ahmed, 2016). Thus, if employees perceive their training and development to be adequate, they are likely to return the favour by exhibiting citizenship behaviour to the organisation. Hence, organisations may need to consider training and development as a key practice that encourages organisational citizenship behaviour because it generates plenty of benefits to employees and the organisation at large.

A study on the effect of training and development on organisational citizenship behaviour in private commercial banks in Bangladesh revealed a significant and positive relationship between training and development practices and organisational citizenship behaviour (Rubel \& Rahman, 2018). A similar relationship was found between training and development and employee's organisational citizenship behaviour (Ahmed, 2016; Tang \& Tang, 2012). Narang and Singh (2012) concluded that training and development practices have significant positive effect on organisational citizenship behaviour.

Contrary to these findings, a negative relationship between training and development and organisational citizenship behaviour was found (Patil \& Ramanjaneyalu, 2018). Although these relationships were found, no study on these study variables could be found in the higher education sector, hence the need to investigate further.

To achieve a competitive advantage, it is important for big organisations such as universities to improve or enhance organisational citizenship behaviours amongst their employees. The human resource management department needs to provide human resource practices (HRP), such as compensation systems and training and development that are fair and inclusive for employees to demonstrate good citizenship to their organisations. The South African higher education system is not immune to challenges of redressing the past gender and income imbalances amongst their workforce. Therefore, the sector should be gender-sensitive in order to promote organisational citizenship behaviour. Similarly, Cloninger, Ramamoorthy and Flood (2011) argued that organisations should develop reward systems, which promote cooperation instead of competition in order to cultivate organisational citizenship behaviour amongst its workforce. Cloninger et al. (2011) found that women display higher citizenship behaviour than men when rewards are more equitable. In line with gender socialisation and social role theory, women are naturally more relationship-oriented and thus may present greater organisational citizenship behaviours than men (Cloninger et al., 2011). Therefore, 
organisations should be gender-sensitive when compensating and empowering their employees in order to promote high citizenship behaviour. In contrast, a study by Meng, Hein, Huey, Cheik and Hui (2014) found an insignificant difference in organisational citizenship behaviour between genders.

\section{Problem statement}

Research on the influence of compensation and training and development on organisational citizenship behaviour is not new. However, the studies were carried out in different sectors such as telecommunications and banking (Ahmed, 2016; Ibrahimet al., 2013; Jahan, 2015) outside South Africa (Tashtoush \& Eyupoglu, 2020). Little is known about citizenship behaviour in the higher education sector in general and in South African rural-based institutions of higher learning in particular. One of the purposes of higher education is to provide quality learning to students. Achieving this depends to a large extent on the level of citizenship behaviour of academic staff, 'availability of adequate number of capable academic staff, who are fully representative of a democratic South Africa' (DHET, 2013). This may be promoted through perceived good compensation systems and employee development programmes. Therefore, it is important to investigate whether similar results can be found in the South African higher education sector.

Previous studies mainly focused on the influence of human resource management practices on variables such as employee organisational commitment (Valeau \& Paille, 2019), productivity or performance (Atteya, 2012; Hassan, 2016) and job satisfaction (Madanat \& Khasawneh, 2018). However, there is dearth of knowledge about compensation, training and development as HRP in relation to organisational citizenship behaviour amongst academic staff in the higher education sector. Therefore, this study seeks to investigate the influence of compensation and training and development on organisational citizenship behaviour amongst academic staff at a selected comprehensive South African higher education institution.

\section{Research objectives}

The objectives of this study were as follows:

- to investigate the influence of compensation on employees' organisational citizenship behaviour amongst the academic staff

- to investigate the influence of training and development practices on organisational citizenship behaviour amongst academic staff

- to determine whether both compensation and training and development are predictors of organisational citizenship behaviour amongst academic staff

- to determine whether there is a significant difference in the mean organisational citizenship behaviour scores for men and women.

This article will give recommendations on possible strategies of improving employee organisational citizenship behaviour amongst academics in higher learning institutions based on the study's findings.

\section{Research hypotheses}

The present study hypothesised that:

H1: There is a positive and significant relationship between compensation and employee organisational citizenship behaviour amongst academic staff.

H2: There is a positive and significant relationship between training and development and employee organisational citizenship behaviour amongst academic staff.

H3: Both compensation and training and development are predictors of employee organisational citizenship behaviour amongst academic staff.

H4: There is a statistically significant difference in the mean scores of males and females in terms of their organisational citizenship behaviour levels amongst academic staff.

\section{Methodology Research design}

The study was based on quantitative approach, using a cross-sectional research design. A total of 152 academics at a selected rural-based comprehensive institution of higher learning were purposively selected to participate in this study regardless of their type of employment contract.

\section{Research participants}

A sample of 152 respondents was purposively selected at a rural-based comprehensive university in the Limpopo province of South Africa, using Raosoft sample size online calculator software. Results in Table 1 show that the majority, $82(54 \%)$ were females, whereas there were 70 males $(46 \%)$. The majority of the respondents were between 30 and 39 years and 40-49 (29.6\%) years age-group, respectively. The lowest number of respondents were respondents between

TABLE 1: Demographic information $(N=152)$.

\begin{tabular}{|c|c|c|c|}
\hline Variable & Category & Frequency & $\%$ \\
\hline \multirow[t]{3}{*}{ Gender } & Male & 70 & 46.1 \\
\hline & Female & 82 & 53.9 \\
\hline & Total & 152 & 100.0 \\
\hline \multirow[t]{6}{*}{ Age (years) } & $20-29$ & 13 & 8.6 \\
\hline & 30-39 & 45 & 29.6 \\
\hline & $40-49$ & 45 & 29.6 \\
\hline & $50-59$ & 36 & 23.6 \\
\hline & 60 and above & 13 & 8.6 \\
\hline & Total & 152 & 100.0 \\
\hline \multirow[t]{4}{*}{ Highest qualification } & Honours & 56 & 37.0 \\
\hline & Masters & 55 & 36.0 \\
\hline & Doctoral & 41 & 27.0 \\
\hline & Total & 152 & 100.0 \\
\hline \multirow[t]{4}{*}{ Contract type } & Full time & 139 & 91.5 \\
\hline & Part time & 9 & 5.9 \\
\hline & Fixed term contract & 4 & 2.6 \\
\hline & Total & 152 & 100.0 \\
\hline \multirow[t]{5}{*}{ Work experience } & Less than 2 years & 35 & 23.0 \\
\hline & $3-5$ years & 79 & 52.0 \\
\hline & $6-8$ years & 25 & 16.4 \\
\hline & 9 years and above & 13 & 8.6 \\
\hline & Total & 152 & 100.0 \\
\hline
\end{tabular}


20 and 29 years old and 60 years and above age-groups. Moreover, the majority of the respondents 56 (37\%) had a Masters degree as their highest qualification and were employed on a full-time basis 139 (91\%). Furthermore, $79(52 \%)$ respondents had been in the academic profession from 3 to 5 years, followed by those who had served in the academic profession for less than 2 years (35) representing $23 \%$ of the respondents.

\section{Instruments}

A self-administered questionnaire that comprised of different instruments to measure demographic characteristics, training and development, compensation and organisational citizenship behaviour was used to obtain information from a sample of 152 academic staff. To measure compensation, Tessema and Soeters' (2006) HRP scale, which contains eight items on compensation practices was used. This scale was previously used by Terera and Ngirande (2014) and an alpha coefficient of 0.82 was found. Snell and Deans' (1992) training and development scale was used to measure training and development and is a five-item index intended to collect data on how extensive staff development policies and procedures function. Its previous Cronbach's alpha value was 0.89 (Khan \& Rasheed, 2015). Organisational citizenship behaviour was measured using the 24-item scale established by Podsakoff, MacKenzie, Moorman and Fetter (1990). From a previous study, the scale has found a Cronbach's alpha value of above 0.7 (Kung, Kwok, \& Brown, 2018). All scales were measured on a 5 -point Likert scale ranging from $1=$ strongly agree to $5=$ strongly disagree.

\section{Data analysis}

The Statistical Package for the Social Sciences (SPSS) version 26 was used to analyse data. Item analysis was performed to inspect the internal consistency of variables under investigation. Exploratory factor analysis was conducted to determine the dimensionality of the scales. Correlation and multiple regression analysis were conducted to test the relationship between compensation, training and development and organisational citizenship behaviour and to determine which variable between compensation and training and development had a significant predictive value to organisational citizenship behaviour amongst the academic staff. $t$-Tests were also conducted to determine whether there is a significant difference in the mean organisational citizenship behaviour scores for male and female academic staff.

\section{Research procedure and ethical considerations}

To collect the data, questionnaires were distributed physically to the academic staff. Respondents were informed about how the data would be collected and their privacy handled. To preserve the anonymity of the respondents, no personal identifiers such as names or office numbers were requested during the research process.

\section{Results \\ Descriptive statistics and scale reliability}

Table 2 gives a summary of the key descriptive statistics on compensation, training and development and organisational citizenship behaviour scales by showing mean and standard deviations. The normality of the data set was also assessed using skewness and kurtosis values. Cronbach's alphas are also presented. The mean scores of compensation, training and development and organisational citizenship behaviour were $2.8(\mathrm{SD}=2.868), 2.4(\mathrm{SD}=1.544)$ and $2.0(\mathrm{SD}=3.146)$, respectively. This implies that most respondents were in agreement with the statements. Data were also normally distributed to allow for further analysis as it ranges from -2 to 2 for skewness (Tabachinick \& Fidell, 2013) and -3 to 3 for kurtosis.

The reliability of the instruments was also shown using Cronbach's alpha coefficients as shown in Table 2. Items correlating below 0.30 with the total score were considered as poor items and were excluded from further analysis (Pallant, 2016). The compensation, training and development and organisational citizenship behaviour scales obtained good coefficient alphas of 0.70, 0.73 and 0.71, respectively (Pallant, 2016).

\section{Exploratory factor analysis}

The principal component analysis was carried out using the varimax rotation method. The compensation scale obtained an acceptable Kaiser-Meyer-Olkin measure of sampling adequacy value of 0.64 whilst the Bartlett's test of sphericity statistic value was $141.64(d f=6 ; p=0.000)$ (Pallant, 2016). One factor was produced, explaining 54\% of the variance. The training and development scale also obtained an acceptable Kaiser-Meyer-Olkin measure of sampling adequacy value of 0.59 and Bartlett's test of sphericity statistic value was $26.13(d f=3 ; p=0.000)$. The scale was found to be unidimensional that explained $50 \%$ of the variance. Furthermore, the organisational citizenship behaviour scale obtained an acceptable Kaiser-Meyer-Olkin measure of sampling adequacy value of 0.62 and Bartlett's test of sphericity statistic value of $232.07(d f=28 ; p=0.000)$ (Pallant, 2016). Two factors were found: Factor one explained $28 \%$ and factor two explained $22 \%$ of the variance, to explain a total variance of $50 \%$. The retained items for the three scales are shown in Table 3.

\section{Hypothesis testing: Correlations results}

The Pearson product moment correlation was used to investigate the relationship between compensation, training

\begin{tabular}{|c|c|c|c|c|c|}
\hline Scale & Mean & SD & Skewness & Kurtosis & Cronbach's alpha \\
\hline Compensation & 2.8 & 2.868 & 0.196 & -0.396 & 0.70 \\
\hline$T \& D$ & 2.4 & 1.544 & 1.386 & 2.779 & 0.73 \\
\hline OCB & 2.0 & 3.146 & 0.609 & 0.928 & 0.71 \\
\hline
\end{tabular}
$\mathrm{OCB}$, organisational citizenship behaviour; SD, standard deviation; T\&D, training and development. 
TABLE 3: Compensation, training and development and organisational citizenship behaviour scale.

\begin{tabular}{|c|c|c|c|c|}
\hline Scale & Item & $\begin{array}{l}\text { Factor } \\
\text { loadings }\end{array}$ & Eigen values & Total variance (\%) \\
\hline \multirow[t]{5}{*}{ Compensation } & Factor 1 & - & 2.1 & 54 \\
\hline & 1. Pay increments offered by my organisation are satisfactory. & 0.831 & - & - \\
\hline & 2. I am satisfied with the benefits I receive. & 0.780 & - & - \\
\hline & 3. My organisation decides compensation based on employee competency or ability. & 0.585 & - & - \\
\hline & 4. In my organisation, salary and other benefits are comparable to the market. & 0.710 & - & - \\
\hline \multirow{4}{*}{$\begin{array}{l}\text { Training and } \\
\text { development }\end{array}$} & Factor 1 & - & 1.5 & 5 \\
\hline & $\begin{array}{l}\text { 1. My organisation organises contents of the training and development programmes, which are always } \\
\text { relevant to the changing needs of my job. }\end{array}$ & 0.613 & - & - \\
\hline & 2. The training needs of employees in my organisation are assessed based on their performance appraisal. & 0.758 & - & - \\
\hline & 3. My organisation provides equal training opportunities to all employees. & 0.734 & - & - \\
\hline \multirow{9}{*}{$\begin{array}{l}\text { Organisational } \\
\text { citizenship } \\
\text { behaviour }\end{array}$} & Factor 1 & - & 2.3 & 28 \\
\hline & 1. I help others who have heavy workloads. & 0.725 & - & - \\
\hline & 2. I help others who have been absent. & 0.774 & - & - \\
\hline & 3. I help orient new people even though it is not required. & 0.778 & - & - \\
\hline & Factor 2 & - & 1.8 & 22 \\
\hline & 5. I am one of the most conscientious employees. & 0.778 & - & - \\
\hline & 6. I take steps to try to prevent problems with other workers. & 0.463 & - & - \\
\hline & 7. I am mindful of how my behaviour affects other people's jobs. & 0.553 & - & - \\
\hline & 8. I read and keep up with organisation announcements, memos and so on. & 0.803 & - & - \\
\hline
\end{tabular}

and development and organisational citizenship behaviour amongst academic staff. Hypothesis one stated that there is a significant relationship between compensation and organisational citizenship behaviour, and hypothesis two assumed that there is a significant relationship between training and development and organisational citizenship behaviour amongst academic staff.

The results in Table 4 show that there is a significant relationship between compensation and organisational citizenship behaviour ( $r=0.450 ; p=0.000)$, thus confirming hypothesis one. Results also show that there is a significant relationship between training and development and organisational citizenship behaviour $(r=0.287$; $p=0.000)$. This confirmed hypothesis two which stated that there is a significant relationship between training and development and organisational citizenship behaviour.

\section{Regression analysis results}

Regression analysis was carried out to determine which variable between compensation and training and development is the best predictor of organisational citizenship behaviour. Hypothesis three states that both compensation and training and development are predictors of employee organisational citizenship behaviour amongst the academic staff.

In model 1, organisational citizenship behaviour was used as the dependent variable, with compensation and training and development as independent variables. As shown in Table 5, entry of compensation and training and development at the first step of the regression analysis produced a statistically significant model $\left(F_{(2.149)}=12.699 ; p<0.01\right)$ and accounted for $14.6 \%$ of the variance. From the results, compensation $(\beta=0.384 ; t=4.752 ; p<0.01)$ was a significant predictor of organisational citizenship behaviour. Training and
TABLE 4: Correlations between compensation, training and development and organisational citizenship behaviour $(N=152)$.

\begin{tabular}{llccc}
\hline Variable & Statistics & $\mathbf{1}$ & $\mathbf{2}$ & $\mathbf{3}$ \\
\hline 1. Compensation & Pearson Correlation & 1 & - & - \\
& Sig. (2-tailed) & - & - & - \\
2. T\&D & Pearson Correlation & $0.479 * *$ & 1 & - \\
& Sig. (2-tailed) & 0.000 & - & - \\
3. OCB & Pearson Correlation & $0.450 * *$ & $0.287^{* *}$ & 1 \\
& Sig. (2-tailed) & 0.000 & 0.000 & - \\
\hline
\end{tabular}

$\mathrm{OCB}$, organisational citizenship behavior; T\&D, training and development.

**, Correlation is significant at the 0.01 level (2-tailed).

TABLE 5: Compensation and training and development as predictors of organisational citizenship behaviour.

\begin{tabular}{|c|c|c|c|c|c|c|c|}
\hline \multirow[t]{2}{*}{ Model } & \multicolumn{2}{|c|}{$\begin{array}{l}\text { Non-standardised } \\
\text { coefficients }\end{array}$} & \multirow{2}{*}{$\begin{array}{c}\text { Standardised } \\
\text { coefficients } \\
(\beta)\end{array}$} & \multirow[t]{2}{*}{$t$} & \multirow[t]{2}{*}{$p$} & \multirow[t]{2}{*}{$F$} & \multirow[t]{2}{*}{$R^{2}$} \\
\hline & Beta & SE & & & & & \\
\hline (Constant) & 10.910 & 2.317 & - & 8.348 & 0.000 & 12.699 & 0.146 \\
\hline Compensation & -0.421 & 0.089 & 0.384 & 4.752 & $0.000 * *$ & - & - \\
\hline$T \& D$ & -0.014 & 0.165 & -0.007 & -0.088 & 0.930 & - & - \\
\hline
\end{tabular}

Dependent variable: OC.

$\beta$, regression coefficient; $F$, overall significance; $p$, probability value; $R^{2}$, percentage variance explained; SE, standard error; $t$, test; T\&D, training and development.

$* *, p \leq 0.01$.

development was reported as an insignificant predictor of organisational citizenship behaviour $(\beta=-0.007 ; t=-0.088$; $p>0.05)$.

\section{Independent sample $t$-test result}

An independent-sample $t$-test was conducted to compare the organisational citizenship behaviour scores for males and females. The assumptions of independent samples test were checked using the Lavene's test for equality of variances. The results in Table 6 show that there was no significant difference in scores for males $(\mathrm{M}=1.91$; $\mathrm{SD}=2.99)$ and females $(\mathrm{M}=2.0 ; \mathrm{SD}=3.25) ;\left(t_{(150)}=-1.49\right.$, $p=0.140$, two-tailed). The magnitude of the difference in the mean (mean difference $=-0.76,95 \%, \mathrm{CI}:-1.76$ to 
TABLE 6: $t$-Test for Independent samples showing the difference between organisational citizenship behaviour levels based on gender.

\begin{tabular}{lllllllllll}
\hline Variable & Gender & $N$ & Mean & SD & $d f$ & $t$ & $p$ & MD & \multicolumn{2}{c}{$95 \% \mathrm{Cl}$} \\
\cline { 5 - 11 } & & & & & & & & & Lower & Upper \\
\hline OCB & Male & 70 & 1.91 & 2.99 & 150 & -1.49 & 0.140 & 0.76 & -1.76 & 0.25 \\
& Female & 82 & 2.0 & 3.25 & - & - & - & - & - & - \\
\hline
\end{tabular}

$\mathrm{Cl}$, confidence interval; $d f$, degrees of freedom; $\mathrm{MD}$, mean difference; $N$, sample; $\mathrm{OCB}$, organisational citizenship behaviour; $p$, probability value; $\mathrm{SD}$, standard deviation; $t, t$-value.

0.25) was small (eta squared $=0.01$ ) (Pallant, 2016). This implies that regardless of gender, the level of citizenship behaviour of males and females is the same. This finding fails to confirm hypothesis four which states that there is a statistically significant difference in the mean organisational citizenship behaviour scores for male and female academic staff.

\section{Discussion}

This study revealed that all three scales obtained acceptable Cronbach's alpha coefficients $(\alpha)$ according to the guidelines of $\alpha \geq 0.70$ (Pallant, 2016) and Briggs and Cheek (1986) of 0.2-0.4, when using the inter item correlations when scale items are fewer than 10 . The highest reliabilities amongst the scales included organisational citizenship behaviour $(\alpha=0.71)$, followed by compensation $(\alpha=0.70)$. The training and development scale obtained the lowest alpha coefficient $(\alpha=0.50)$. This result might be attributed to the fact that the scale had few items. This is also raised by Pallant (2016), who argued that Cronbach's alpha values are quite sensitive to the number of scale items and it is common to find quite low Cronbach values.

The researchers conducted exploratory factor analyses on the compensation scale, training and development scale, and organisational citizenship behaviour scale. The analysis of the compensation scale and the training and development scale showed that a 1-factor model suits the data in this study best. This is contrary to the three structures previously identified (Siegrist, Wege, Pühlhoferm, \& Wahrendorf, 2009). The exploratory factor analysis on organisational citizenship behaviour scale showed that a 2-factor model suits the data best.

A positive significant relationship between compensation and organisational citizenship behaviour was found. This shows that if compensation is perceived as high or fair, organisational citizenship behaviour also increases. The results confirmed the first hypothesis of the study that there is a significant relationship between compensation and organisational citizenship behaviour amongst academic staff. Several studies support this finding (Makau et al., 2017; Rahman \& Chowdhuri, 2018; Snape \& Redman, 2010), meaning that if employees perceive their salaries and benefits to be fair, their organisational citizenship behaviour will also increase. Thus, the higher education human resource management department should provide compensation systems, which are fairly competitive enough in order to promote employee organisational citizenship behaviour amongst the academic staff.
The results also show that a significant relationship exists between training and development and organisational citizenship behaviour. This shows that as training and development increase in an organisation, employees tend to show citizenship behaviour. This means that as organisations appreciate and empower their employees, the employees will be prepared to go an extra mile in doing their jobs. Therefore, hypothesis two is supported. Previous studies confirm the finding that a positive significant relationship exists between training and development and organisational citizenship behaviour (Tang \& Tang, 2012). Therefore, management in the public higher education sector may need to constantly revise its compensation and staff development policy in order to promote organisational citizenship behaviour amongst academic staff so as to remain competitive.

The regression analysis results also confirm the relationship between compensation and organisational citizenship behaviour and its predictive value to organisational citizenship behaviour. This means that compensation plays a key role in motivating employees to go an extra mile and display extra-role behaviours thereby enhancing the competitive advantage of the organisation. Whilst training and development was found to have a relationship with organisational citizenship behaviour, results revealed that it is not a significant predictor of organisational citizenship behaviour. The reason might be that, people tend to value compensation more than career development opportunities. However, these results are still important as employee behaviour is determined by various organisational aspects, which need to be explored. This will assist organisations to make well-informed policies.

To test hypothesis four which states that there is a significant difference between males and females' levels of organisational citizenship behaviour. Results revealed that both males and females exhibit the same levels of organisational citizenship behaviour. This shows that gender has no influence on one's level of organisational citizenship behaviour. Hence, hypothesis four is not supported.

These findings brought new insights into the importance of compensation and training and development, thus expanding the body of knowledge in promoting organisational citizenship behaviour as there is dearth of knowledge about this phenomenon in the South African higher learning institutions context. Universities can use the study's findings to develop interventions and strategies that promote employee organisational citizenship behaviour.

\section{Limitations}

Whilst this study explored the HRP such as compensation and training and development and the effect thereof on organisational citizenship behaviour for individuals and organisations, it had some limitations. The population of academic staff based on two faculties is too small to generalise these findings to the larger population. A cross-sectional 
sample was employed, which may result in people overthinking their responses on items in the scales. Relatively little enquiry has been carried out on the study variables in South African higher learning institutions, more especially, from a rural based historically black comprehensive university, which makes it difficult to relate the findings to the South African context.

\section{Recommendations for future research}

Future studies should consider using a longitudinal design to repeatedly observe and measure the relationship between compensation, training and development and organisational citizenship behaviour of academic staff in higher education over a long period of time. Future research could address the limitations of the generalisation of the study results by using a larger sample size of faculties and a greater number of higher education institutions to take part in studies of this nature.

\section{Implications}

The South African higher education sector has a challenge of an ageing workforce and academic staff working in a mass education system (DHET, 2015; Pienaar \& Bester, 2008). The new knowledge gained from observing the relationships between compensation and training and development may be useful in making sure that the management should not overlook the importance of compensation, training and the development of its workforce if it wants to promote organisational citizenship behaviour in the higher education sector, especially the black and young academic staff because of their high mobility. Furthermore, the information gained can be useful in retaining black and female academic staff as a way of addressing their very serious under-representation at all levels in the higher learning sector as alluded to in the Department of Higher Education and Training's Staffing South Africa's Universities Framework (DHET, 2013). The results suggest that in order to have employees who exhibit citizenship behaviour to their respective organisations and to fellow employees, managers need to review existing human resource management practices and policies such as compensation and training and development opportunities for their employees.

\section{Conclusion}

The aim of this study was to investigate the influence of compensation practices and training and development on organisational citizenship behaviour amongst academic staff at a selected South African rural institution of higher learning. The study results revealed that indeed, compensation and training and development have an influence on the organisational citizenship behaviour of employees. Thus, compensation and training and development can be viewed as valuable HRP that should be constantly monitored in order to promote organisational citizenship behaviour amongst employees.

\section{Acknowledgements}

The authors would like to acknowledge Dr Sharon Ruvimbo Terera for assistance with some statistical analysis and Professor Sherran Clarence for guidance in writing this article.

\section{Competing interests}

The authors declare that they have no financial or personal relationships that may have inappropriately influenced them in writing this article.

\section{Authors' contributions}

P.M.M. is an honours student who initialised the research topic, collected the data and wrote much of the article under the supervision of H.N.

\section{Funding information}

This research received no specific grant from any funding agency in the public, commercial or not-for-profit sectors.

\section{Data availability}

The data that support the findings of this study are available from the corresponding author, H.N., upon reasonable request.

\section{Disclaimer}

The views and opinions expressed in this article are those of the authors and do not necessarily reflect the official policy or position of any affiliated agency of the authors.

\section{References}

Ahmed, N.O.A. (2016). Impact of human resource management practices on organisational citizenship behaviour: An empirical investigation from the banking sector of Sudan. International Review of Management and Marketing, 6(4), 964973.

Atteya, N.M. (2012). Testing the impact of human resource management practices on job performance: An empirical study in the Egyptian joint venture petroleum companies. International Journal of Business and Social Science, 3(9), 105-119.

Boardman, A.E., Greenberg, D.H., Vining, A.R., \& Weimer, D.L. (2017). Cost-benefit analysis: Concepts and practice. New York, NY: Cambridge University Press.

Bonaparte, W. (2008). The impact of organizational citizenship behaviour and organizational commitment on organizational performance. Unpublished PhD thesis, Nova South-Eastern University, FL.

Boughey, C., \& McKenna, S. (2016). Academic literacy and the decontextualised learner. Critical Studies in Teaching and Learning, 4(2), 1-9.

Bozalek, V., \& Boughey, C. (2012). (Mis)framing higher education in South Africa. Social Policy and Administration, 46(6), 688-703. https://doi.org/10.1111/j.1467 9515.2012.00863.x

Briggs, S.R., \& Cheek, J.M. (1986). The role of factor analysis in the development and evaluation of personality scales. Journal of Personality, 54(1), 106-148. https:// doi.org/10.1111/j.1467-6494.1986.tb00391.x

Bussin, M. (2011). The remuneration handbook for Africa. A practical and informative handbook for managing reward and recognition in Africa. Randburg: Knowres Publishing.

Bussin, M.H., \& Brigman, N. (2019). Evaluation of remuneration preferences of knowledge workers. SA Journal of Human Resource Management, 17(1), 1-10. https://doi.org/10.4102/sajhrm.v17i0.1075

Chattopadhyay, R. (2017). Impact of forced distribution system of performance evaluation on organisational citizenship behaviour. Global Business Review, 20(3), 826-837. https://doi.org/10.1177/0972150917721819

Chenga, S.A. (2018). Effectiveness of workers compensation practices in public organisations. Doctoral dissertation, The Open University of Tanzania.

Chin, E.W., Ho, C.S., Lim, K.K., Loh, W.S., \& Low, K.S. (2017). Strategic human resource management and job satisfaction toward organisational citizenship behaviour. Doctoral dissertation, Universiti Tunku Abdul Rahman. 
Cloninger, P.A., Ramamoorthy, N., \& Flood, P.C. (2011). The influence of equity, equality, and gender on organisational citizenship behaviours. S.A.M. Advanced Management Journal, 76(4), 37-47.

David, M. (2013). CEO and employee pay discrepancy: How the government policies have encouraged the gap. Journal of Business, Entrepreneurship and the Law, 6(2), 298-325.

Dekas, K.H., Bauer, T.N., Welle, B., Kurkoski, J., \& Sullivan, S. (2013). Organisational citizenship behaviour: A review and qualitative investigation of organisational citizenship behaviours for knowledge workers at Google and beyond. Academy of Management Perspectives, 27(3), 219-237. https://doi.org/10.5465/amp. 2011.0097

Department of Higher Education and Training (DHET). (2013). White paper for post school education and training. Pretoria: Government Printers.

Department of Higher Education and Training (DHET). (2015). Foreword by the Minister, Dr B.E. Nzimande. Department of Higher Education and Training. Retrieved from http://www.ssauf.dhet.gov.za

Elnagal, A., \& Imran, A. (2013). The effect of training on employee performance. European Journal of Business and Management, 5(4), 137-147.

Ford, J.K., Kraiger, K., \& Merritt, S. (2010). The multidimensionality of learning outcomes revisited. In S.W.J. Kozlowski \& E. Salas (Eds.), Learning, training, and development in organizations (pp. 135-165). Mahwa, NJ: Erlbaum.

Hassan, S. (2016). Impact of human resource management practices on employee's performance. International Journal of Academic Research in Accounting, Finance and Management Sciences, 6(1), 15-22.

Ibrahim, R., Ghani, M., \& Salleh, A. (2013). Evaluating organisational citizenship behaviour among local government employees: The mediating role of job satisfaction. Asian Social Science, 9(13), 92-104.

Jahan, S. (2015). Employee training and development system of banking sector of Bangladesh: An empirical study on Eastern Bank Ltd. Daffodil Internationa University Journal of Business and Economics, 8(1), 35-56.

Kim, K., Halliday, C.S., Zhao, Y., Wang, C., \& Von Glinow, M.A. (2018). Rewarding self-initiated expatriates: A skills-based approach. Thunderbird International Business Review, 60(1), 89-104

Khan, A.S., \& Rasheed, F. (2015). Human resource management practices and project success, a moderating role of Islamic work ethics in Pakistani project-based organisations. International Journal of Project Management, 33(2), 435-445. https://doi.org/10.1016/j.ijproman.2014.08.006

Kolade, O.J., Oluseye, O.O., \& Omotayo, O. (2014). Organisational citizenship behaviour, hospital corporate image, and performance. Journal of Competitiveness, 6(1), 36-49. Https://doi.org/10.7441/joc.2014.01.03

Kung, F.Y., Kwok, N., \& Brown, D.J. (2018). Are attention check questions a threat to scale validity? Applied Psychology, 67(2), 264-283. https://doi.org/10.1111/ apps.12108

Madanat, H.G., \& Khasawneh, A.S. (2018). Level of the effectiveness of human resource management practices and its impact on employees' satisfaction in the banking sector of Jordan. Journal of Organisational Culture, Communications and Conflict, 22(1), 1-19.

Makau, M.M., Nzulwa, J., \& Wabala, S.W. (2017). Influence of compensation programs on organisational citizenship behaviour among employees of Kenya Women Microfinance Bank Limited. The Strategic Journal of Business \& Change Management, 4(32), 587-604.

Meng, C.C., Hein, F.C, Huey, L.J., Cheik, L.W., \& Hui, L.M. (2014). Human resource management practices as a determinant of organizational citizenship behaviour: A study among banking staffs. Honours dissertation, Universiti Tunku Abdul Rahman.

Milkovich, G., Newman, J., \& Gerhart, B. (2013). Compensation (11th ed.). New York, NY: McGraw-Hill Education.

Mohamedbhai, G. (2014). Massification in higher education institutions in Africa: Causes, consequences and responses. International Journal of African Higher Education, 1(1), 59-83. https://doi.org/10.6017/ijahe.v1i1.5644

Morales-Sánchez, R., \& Pasamar, S. (2019). How to improve organisational citizenship behaviour by combining ability, motivation and opportunity. Employee Relations: The International Journal, 2(2), 398-416. https://doi.org/10.1108/ER-04-2019The Inter
0169

Narang, L., \& Singh, L. (2012). Role of perceived organizational support in the relationship between human resource practices and organisational trust. Global relationship between human resource practices and organisational trust. Global
Business Review, 13(2), 239-249. https://doi.org/10.1177/097215091201300204

Odunlade, R.O. (2012). Managing employee compensation and benefits for job satisfaction in libraries and information centres in Nigeria. Library Philosophy and Practice, Paper 714

Olson, E.M., Slater, S.F., Hult, G.T.M., \& Olson, K.M. (2018). The application of human resource management policies within the marketing organization: The impact on business and marketing strategy implementation. Industrial Marketing Management, 69, 62-73.

Organ, D.W. (1988). Organisational citizenship behaviour: The good soldier syndrome Lexington, MA: Lexington Books.

Organ, D.W., Podsakoff, P.M., \& Mackenzie, S.B. (2006). Organisational citizenship behaviour: Its nature, antecedents, and consequences. Thousand Oaks, CA: Sage.

Owor, J.J. (2016). Human resource management practices, employee engagement and organisational citizenship behaviours in selected firms in Uganda. African Journa of Business Management, 10(1), 1-12. https://doi.org/10.5897/AJBM2015.7954
Pallant, J. (2016). SPSS survival manual: A step by step guide to data analysis using SPSS (6th ed.). London: McGraw-Hill.

Patil, T., \& Ramanjaneyalu, N. (2018). Impact of human resource development functions on organisational citizenship behaviour. International Online Multidisciplinary Journal, 8(3), 71-80.

Pienaar, C., \& Bester, C.L. (2008). The retention of academics in the early career phase: Empirical research. SA Journal of Human Resource Management, 6(2), 32-41. https://doi.org/10.4102/sajhrm.v6i2.171

Podsakoff, P.M., MacKenzie, S.B., Moorman, R.H., \& Fetter, R. (1990). Transformational leader behaviours and their effects on followers' trust in leader, satisfaction, and organisational citizenship behaviours. The Leadership Quarterly, 1(2) 107-142. https://doi.org/10.1016/1048-9843(90)90009-7

Rahman, H.A., \& Chowdhuri, M.B. (2018). Effect of employee compensation on organisational citizenship behaviour: A study on private commercial banks in Bangladesh. International Journal of Economics, Commerce and Management 6(5), 848-863.

Rawabdeh, M., Nawafleh, S., Alsari, H., \& Melhem, M.B. (2019). The mediating influence of organisational citizenship behaviour on employee job performance and staff incentive's relationship. International Journal of Management Practice, 12(2), 200-227. https://doi.org/10.1504/IJMP.2019.098655

Rubel, M., \& Rahman, M.H.A. (2018). Effect of training and development on organisational citizenship behaviour: An Evidence from private commercial banks in Bangladesh. Global Journal of Management and Business Research, 18(8), 70-80.

Salas-Vallina, A., Alegre, J., \& Fernandez, R. (2017). Happiness at work and organisational citizenship behaviour. International Journal of Manpower, 38(3) 470-488. https://doi.org/10.1108/IJM-10-2015-0163

Siegrist, J., Wege, N., Pühlhofer, F., \& Wahrendorf, M. (2009). A short generic measure of work stress in the era of globalisation: Effort-reward imbalance. Internationa Archives of Occupational and Environmental Health, 82(8), 1005-1013. https:// doi.org/10.1007/s00420-008-0384-3

Smit, R. (2012). Towards a clearer understanding of student disadvantage in higher education: Problematising deficit thinking. Higher Education Research \& Development, 31(3), 369-380. https://doi.org/10.1080/07294360.2011.634383

Snape, E., \& Redman, T. (2010). Human resource management practices, organisational citizenship behaviour, and performance: A multi-level analysis. Journal of Management Studies, 47(7), 1219-1247. https://doi.org/10.1111/j.14676486.2009.00911.x

Snell, S.A., \& Dean, J.W. (1992). Integrated manufacturing and human resource management: A human capital perspective. Academy of Management Journal, 35(3), 467-504. https://doi.org/10.2307/256484

Suryani, N.N., Gama, G., \& Parwita, S.G. (2019). The effect of organisational compensation and commitment to organisational citizenship behaviour in cooperative and small, middle enterprises department of Bali Province. International Journal of Contemporary Research and Review, 10(1), 21210-21218. https://doi.org/10.15520/ijcrr.v10i01.643

Tabachinick, B.G., \& Fidell, L.S. (2013). Using multivariate statistics (6th ed.). Boston, MA: Pearson Education.

Tang, T.W., \& Tang, Y.Y. (2012). Promoting service-oriented organisational citizenship behaviours in hotels: The role of high-performance human resource practices and organisational social climates. International Journal of Hospitality Management, 31(3), 885-895. https://doi.org/10.1016/j.ijhm.2011.10.007

Tashtoush, L., \& Eyupoglu, S.Z. (2020). The relationship between human resource management practices and organisational citizenship behaviour. South African Journal of Business Management, 51(1), 1-11. https://doi.org/10.4102/sajbm. v51i1.1726

Teferra, D. (2015). Africa's troika conundrums: Expansion, consolidation, and un(der) employment? International Higher Education, 80(1), 18-19. https://doi. org/10.6017/ihe.2015.80.6148

Terera, S.R., \& Ngirande, H. (2014). The impact of training on employee job satisfaction and retention among administrative staff members: A case of a selected tertiary
institution. Journal of Social Sciences, 39(1), 43-50. https://doi.org/10.1080/0971 institution. Journal of

Tessema, M., \& Soeters, J. (2006). Challenges and prospects of human resource management in developing countries: Testing the human research managementperformance link in Eritrean civil service. International Journal of Human Resource performance link in Eritrean civil service. International Journal of Human Resou
Management, 17(1), 86-105. https://doi.org/10.1080/09585190500366532

Theron, M., Barkhuizen, N., \& Du Plessis, Y. (2014). Managing the academic talent void: Investigating factors in academic turnover and retention in South Africa. SA Journal of Industrial Psychology, 4O(1), 1-14. https://doi.org/10.4102/SAJIP. Journal of

Valeau, P.J., \& Paillé, P. (2019). The management of professional employees: Linking progressive human resource management practices, cognitive orientations, and organisational citizenship behaviour. International Journal of Human Resource Management, 30(19), 2705-2731. https://doi.org/10.1080/09585192.2017. Managemer
1332671

Zehra, N. (2016). Training \& development barometer for effective transformation of organisational commitment and overall performance in banking sectors of KPK, Pakistan: Qualitative study of workforce of Bank of Khyber. International Journal of Academic Research in Business and Social Sciences, 6(6), 246-267. https://doi. org/10.6007/IJARBSS/v6-i6/2196 